\title{
Foresight in cities
}

DOI:

10.1108/FS-06-2015-0037

\section{Document Version}

Accepted author manuscript

Link to publication record in Manchester Research Explorer

\section{Citation for published version (APA):}

Ravetz, J., \& Miles, I. (2016). Foresight in cities: on the possibility of a "strategic urban intelligence". Foresight, 18(5), 469-490. https://doi.org/10.1108/FS-06-2015-0037

\section{Published in:}

Foresight

\section{Citing this paper}

Please note that where the full-text provided on Manchester Research Explorer is the Author Accepted Manuscript or Proof version this may differ from the final Published version. If citing, it is advised that you check and use the publisher's definitive version.

\section{General rights}

Copyright and moral rights for the publications made accessible in the Research Explorer are retained by the authors and/or other copyright owners and it is a condition of accessing publications that users recognise and abide by the legal requirements associated with these rights.

\section{Takedown policy}

If you believe that this document breaches copyright please refer to the University of Manchester's Takedown Procedures [http://man.ac.uk/04Y6Bo] or contact uml.scholarlycommunications@manchester.ac.uk providing relevant details, so we can investigate your claim.

\section{OPEN ACCESS}




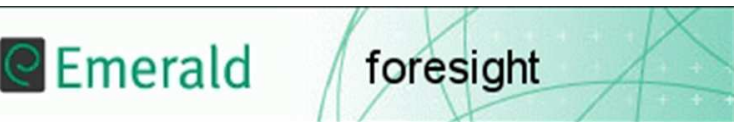

\section{Foresight in cities: on the possibility of a 'strategic urban intelligence'}

\begin{tabular}{|r|l|}
\hline Journal: & Foresight \\
\hline Manuscript ID & fs-06-2015-0037.R1 \\
\hline Manuscript Type: & Original Article \\
\hline Keywords: & $\begin{array}{l}\text { Forward planning, Organizational Learning, Transition management, } \\
\text { strategic policy intelligence, Scenario methods, Urban policy }\end{array}$ \\
\hline \multicolumn{2}{|l}{} \\
\hline
\end{tabular}

\section{SCHOLARONE \\ Manuscripts}




\section{Foresight in cities: on the possibility of a 'strategic urban} intelligence'

\section{INTRODUCTION}

Cities are highly permanent artifacts, the most tangible of all human creations. Their infrastructure and built structures are slow and costly to produced, with lifetimes of indefinite extent. So, urban planning aims in principle to provide a long term futures perspective based on strategic policy intelligence. But the reality is often different: urban planning is hindered by lack of evidence, lack of financial power, political pressures and disconnection of citizens from government. This suggests an essential role for a city-level foresight process, not just as a one-off futures study, but embedded into urban policy and urban institutions. A successful foresight would build capacity for social learning and collective intelligence, and anticipatory governance, but again the reality is lacking and good examples are short-lived.

At this moment, however, there are developments in governance and informatics, and these could offer potential for real progress in the UK and similar countries. This paper aims to respond with a theoretical framework and practical examples. It addresses three main questions in three main sections:

a) How to analyse city-level foresight, as a social learning process for urban system collective intelligence (urban co-intelligence) and co-evolutionary change? (Section 2). This draws on a framework and methodology for 'synergistics', developed for such questions (Ravetz 2014 \& 2015). It also draws on a framework for analysis and evaluation of foresight and its tools (Miles, 2012: Eerola and Miles 2010)

b) How do recent examples of city-level foresight, from the UK Foresight on 'Future of Cities' program, look from these perspectives? (Section 3).

c) Following on (a) and (b), what would a next generation of city foresight look like? (Section 4). Here we set out some principles for a generic 'City Foresight Platform', together with one example of work in progress.

The conclusion reviews the overall potential for cities and their strategic urban intelligence to be improved by adopting foresight methods: and the implications for foresight methods of doing that. 


\section{Background}

Climate change, urban poverty, financial instability and many other 'grand challenges' of the $21^{\text {st }}$ century, are not easily tackled with current systems of strategy and decision-making, in either public or private sectors (DG REGIO, 2011). This also applies to problems for cities in the UK, such as the North-South divide, the housing crisis, low productivity and social fragmentation. But at present much urban policy and governance appears to be short-termist, disconnected, and lacking capacity to 'join the dots'.

This calls for more radical and creative thinking at all levels. One approach is with strategic and futures thinking, and particularly the methods and tools known as foresight. Looking into the future, building the best evidence and acting on the implications, should in principle be a key role of urban policy and governance. But in reality it seems there are so many barriers and gaps, pressures and crunches, that public policy often doesn't get near to the future: and when it does, such knowledge is often problematic.

\section{City devolution context}

Following the UK General Election 2015, the Chancellor invited "England's big cities to join Manchester in bidding for devolved powers, as long as they agree to be governed by a directly elected mayor" (Tomaney and McCarthy 2015). This so-called 'Devo-Manc' model could be potentially a major change in the fortunes of major cities: or it could be set up to fail, as in Moran \& Williams (2015):

"... 'devo Manc' is not doing enough if it only offers bits of money and devolved authority to an elected mayor, whose role will be to manage more cuts and preside over unsolved structural problems. Centralisation has certainly disappointed, but this kind of 'devo Manc' decentralisation is bound to fail."

Whether or not successful, the 'Devo' agenda is topical and urgent, and at the moment seems to crowd out discussion of longer term issues. But behind the rhetoric and excitement about new political structures, there are deep concerns: lack of political trust: low productivity: divided and insecure society: crumbling infrastructure: regional disparities, and so on. Cities in the UK may shortly have more aspiration with less resources to fulfil them. It follows, that building their native 
capacity for learning, collaboration, strategic thinking and shared intelligence, may be the only option for real progress.

Meanwhile in Europe, many cities and city-regions seem to enjoy longer range strategic planning for 20-40 year horizons (CoR, 2011). A major European Commission initiative on 'Cities for Tomorrow' linked a diverse urban agenda with reform of the Cohesion Funds (DG REGIO, 2011). But from UK city foresight projects, there is a common view, that what knowledge there is not well connected: that simplistic policies ignore complex problems, and that strategic planning is locked in departmental silos. For instance the UK National Infrastructure Plan contains few links to the urban or spatial dimensions of housing, economic, environmental or other social policies (TCPA, 2015). The projections for transport and other infrastructure are often based on narrow 'business as usual' projections, leaving out other possibilities. And in the current hollowing out of UK strategic governance, the public policy and evidence gap can only be filled ad-hoc by external organizations (Wong et al, 2012).

The examples in this paper are based on recent and ongoing national and local programs, as in Section 3 below, which include at the time of writing: a national project on the 'Future of Cities' in the UK, , run by the Government Office of Science: and an academic network studying local applications in four cities / city-regions, Greater Manchester, Newcastle, Cardiff and Reading: also there is a wider 'City Visions' community of 22 cities with some foresight-related activities.

\section{Mapping foresight: the co-evolutionary approach}

The background to city-level foresight is as old as urban planning itself. The first explicit attempts to bring together future studies, urban studies and ecological thinking emerged in the 1990s, with the parallel agendas of complex systems analysis, innovation, transition and technology assessment. One initiative was the 'Sustainable City-Region', which set out a strategic view of the city-region and the 'inter-connections of things', with integration of social / economic / environmental problems, with application to goals, targets and strategies (Ravetz 2000). Promoting this model in many cities and regions, brought front-line experience of the 'policy gap' between aspirations and reality, and the challenge of integration between actors and sectors. In response, a next generation concept began to emerge, the 'Synergistic City-Region': this is more about 'inter-connections of thinking', and the potential for social learning and an urban collective or 'co-intelligence' (Ravetz 2014).

One of the most important enablers of this urban co-intelligence is the practice of foresight: a package of methods and tools for strategic policy intelligence, of organizations, policies, 
governments and technologies (Loveridge, 2009). While in principle this seems logical, in practical application to cities it seems there are many barriers. Cities aren't generally freestanding units: they are more like hubs in a network, pulled by global forces of finance or technology, and strategic planning with foresight often runs into vested interests (Fernandez-Guell and Redondo, 2012).

One way forward is with a co-evolutionary approach, which explores the potential for system change and transformation, and this can use a set of methods and tools known as 'synergistics' (Ravetz, 2015). As in the next section, this identifies three levels or framings of complexity and coevolutionary change. In summary, there's a 'linear' (1.0) model of foresight, with a deterministic frame. An 'evolutionary' (2.0) model of foresight is more focused on adaptive innovation . By contrast is a 'co-evolutionary' 3.0 model of 'Synergy-Foresight': focused on co-learning, co-creation and co-intelligence, not only within the foresight programme, but across the wider city and its economies, governances and technologies (Mulgan, 2014: Cohen, 2012: Ravetz, 2013 and 2014). This three-level model can be seen in many applications. For example, in the housing retrofit case in Section 4, a 'linear' model is about numbers of units: an evolutionary model is more about incentives and markets: and the 'co-evolutionary' model is about the cognitive-collaborative community of actors in retrofit. The next step is to map this three-layer model onto different domains: the foresight 'subject' (the persons or agents involved): the foresight 'object' (the agenda or object of enquiry): and the foresight 'processes' (methods, tools, programs etc). In each, there are visible contrasts between 'linear' or 'evolutionary', and a more 'co-evolutionary' frame and way of thinking. A key component of foresight is the 'vision thing'. Values and priorities, aspirations and ambitions, 'success scenarios' and similar, are each facets of a 'normative future' (Bezold, 2013). If policy was a simple thing it would translate the visions into tangible goals, objectives, targets, road-maps and strategies. In reality nothing is simple, and a typical foresight exercise often sees both visions and plans tangled up with the 'probable, plausible or preferable' (Ramirez \& Stein 2015). So in the next section we use the synergistic methods to map the combinations of a time axis (present / future), and a normative axis (utopian / dystopian).

Overall, the co-evolutionary approach helps to identify the most relevant framing of a problem: the most suitable kind of foresight response: and the role of foresight as enabler of urban cointelligence. Then we can look at practical applications such as spatial planning, housing and property, transport and infrastructure, ecosystems and climate change, health and education, and many others, each showing the potential of city-level foresight to improve city governance. 


\section{MAPPING FORESIGHT}

Here we look at the principles of foresight as a means of transformation, and apply them to the main components of 'subject, process and object'. In each of these it's clear that there is some kind of transformation effect from the foresight process: but in practice this is often not visible or explicit. For instance, if we run a foresight on urban housing, detailed questions on housing numbers are often entangled with ethics or issues of political economy: complex collaborations between producers intermediaries or users, or the linkages of housing with other fields, are not easy to separate out.

Our experience suggests that if foresight is, (a) more effective in its own terms, and (b) more useful for its wider purpose in building 'strategic urban co-intelligence', we should explore the meaning of such transformations. To do this we introduce the co-evolutionary approach and the methods of 'synergistic mapping and design', in a brief overview of issues covered in other papers (Ravetz 2013, 2014, 2015: Miles 2012).

\section{Co-evolutionary systems \& synergistic thinking}

As a basic research tool, synergistics provides methods suitable for 'cognitive-creative-collaborative' (" $\left.3 C^{\prime \prime}\right)$ systems. Generally these are systems which are highly inter-connected and multi-level, based on mutual learning and reflexive feedback, with capacity for collective or co-intelligence. As an applied research tool, the synergistic approach helps with mapping and analysis of almost any agenda in the STEEP range (social / technical / economic / ecological/ political). Overall, it doesn't aim to be predictive or tractable, and doesn't present a 'theory of everything': but it does point towards a new paradigm, of co-learning, co-creation, co-innovation and co-intelligence to address the so-called Grand Societal Challenges.

The synergistics approach builds on a wide range of literature. One starting point is the concept of wicked problems, or social messes (Rittel and Webber, 1973: Ackoff, 1973): problems or 'problematiques', which are irreducibly complex, open, inter-connected, controversial and reflexive. 
These insights came in parallel with early systems thinking, which tended to look for discreet variables, relationships, and feedbacks: where these are formalized, then a 'viable systems' or system dynamics model can be constructed [Beer, 1966: Meadows, 2008: Bar-Yam, 1997). However many human-centred systems are shaped by more qualitative intangible factors, where more heuristic or actor-centred approaches are more relevant, such as Soft Systems Methodology (Checkland \& Scholes, 1990). More recently systems thinking and system dynamic modelling has been applied to concepts of sustainability and 'adaptive systems', in 'Viable Systems Models', in ecological modeling, or similar agendas on sustainability (Espinosa and Walker, 2011: Folke et al 2002: Waltner-Toews, 2009: Clayton and Radcliffe, 1996). A "functional adaptive system" is based on a simple feedback-response loop, such as a thermostat which regulates a boiler, as described in system dynamics. A 'complex adaptive system' can be seen with self-regulating socio-ecological or similar relational communities, with features such as emergence, self-organization, non-linearity, and co-evolution (Holland, 1998: Buckley, 1998: Brand, 2005). A further level can be framed as a 'complex cognitive system': human-centred systems driven by conscious and strategic intentions, such as policy discourse, learning effects, creative enterprise, cultural reproduction, or generally the co-evolution of co-intelligence (Yang \& Shan, 2008), or 'co-intelligence' (Mulgan 2013: Atlee, 2003).

Beyond the frame of 'socio-ecological' or 'socio-technical' systems (Geels, 2004), the synergistic approach includes for wider "socio-technical-economic-environment-political-value' systems, in other words the 'STEEPV' scheme used in many kinds of foresight work (Loveridge, 2009) (here the variation of 'STEEPC' is used to include 'culture'). In parallel the 'post-normal science' concept responds to uncertainty and controversy in knowledge production and application, and the interaction between knowledge and human 'values' (Funtowicz \& Ravetz, 1994). Various interpretations of this run in parallel, such as the concept of 'problematic knowledge' (Leach et al, 2010): and uncertainty and scientific quality (van der Sluijs et al 2010).

\section{Co-evolution in 1-2-3}

These perspectives - systems, complexity, learning, problematic knowledge, and so on - are brought together as a combination of theory and practice, framed as 'synergistic thinking' (Ravetz, 2014). The first application of this is to identify and map co-evolutionary change, with different levels or conceptual models of system dynamics and structure. Three main types of model are apparent, labeled here as "1-2-3.0":

1) 1.0: linear model: 'functional systems' which respond to direct short term change: (i.e. an image of a large and complicated machine). If urban transport is framed as a machine run 
on command and control lines, it cannot evolve into anything different, although it may be complicated and 'clever'.

2) 2.0: evolutionary model: 'complex adaptive systems', with longer term changes and transitions, with a biological image of 'survival of the fittest' in the jungle. Urban transport here is framed as an evolutionary socio-technical system of adaptation and innovation, successful for some and failing others, with autonomous evolution as a 'smart' city.

3) 3.0: co-evolutionary model: 'complex cognitive systems', shaped by human qualities of colearning, cognition, co-creation and co-production, with a societal image of a civilization. An urban transport can be framed as not only technology and markets, but wider combinations of cultural, social, emotional and ethical values and synergies, as part of a 'wise' city.

The 3.0 model can then be applied to many different domains - e.g. social, technical, economic, environmental, political, culturaland so on (a list summarized here as 'STEEPCU'). The vital factor is the forming of synergies of all kinds, within each domain and between them, and so the model as a whole is framed as 'synergistic'.

\section{Boundary questions and tensions}

Scenario methods are often framed as a simple checklist of 4, 6, 8 or 10 steps (Strategy Unit, 2001: Ringland, 2006: Eerola and Miles, 2011). But practitioners know them more as an art form, needing skilled facilitation and rapport with participants. While participants often struggle with ambiguity and confusion, experienced facilitators know to jump over tricky issues in order to get an output. But some common questions tend to go round and round:

- "how do we know what is outside or inside the 'boundary' of the problem or solution?

- "how do we know what is a driver of change, whether immediate cause, threshold trigger, or an underlying shift, when they are all inter-connected?

- "how can we discuss a major transformation if we have no idea how to achieve it?"

Each of these suggests that the reality of exploring the future is often more 'synergistic' than the simple guidance would suggest. For instance, in the textbooks the 'system boundary' and 'policy boundary' are clear and distinct, but in practice questions arise between the 'drivers of change', 'responses to drivers', 'drivers of responses' and so on. Recent scenario methods are more open to multiple realities, for instance Causal Layer Analysis, and the 'Policy Framework' approach to future- 
oriented policy knowledge (Inayatullah, 2011: Miedzinski, 2015). One example was the UK program of scenario workshops on a 'One Planet' sustainability agenda (Ravetz, 2006). This brought to the surface a bundle of utopian aspirations, entangled with dystopian fears: the apparently rational evidence of the 'ecological footprint' data and targets was translated into a landscape of dilemmas and dissonances, from personal to political.

\section{Synergy Foresight dimensions}

A typical shortcoming of foresight and future studies is a disconnection or mismatch between the process output, and its applications in policy or enterprise - in fact there is often ambiguity and confusion all round. In response, the Synergy-Foresight mapping focuses on synergistic features in four main dimensions - the subject, the process, the agenda and the object. These have similarities to the evaluation of foresight as a 'service encounter' between actors with co-learning and coproduction (Miles, 2012): and similarities to the Global Futures Intelligence System (GFIS) categories of 'experts', 'information', and 'toolkit' of software and hardware (Glenn, 2012). These four dimensions are visualized in in Figure 1 and Figure 2, and each shows a contrast between linear / evolutionary (1.0 and 2.0) models (on the left side of the picture), and the co-evolutionary (3.0) model (on the right hand side).

\section{Foresight subject}

The 'subject' refers to the sponsors, facilitators, experts and other stakeholders in a typical foresight, visualized here as a bundle of overlapping domains based on the STEEPC scheme. In the linear / evolutionary models, on the left of Figure $1 \mathrm{~A}$, the subject is assumed as committees of technocratic experts, policy makers and professionals who are often self-nominating 'insiders': and alternative or critical viewpoints are managed and contained within the required level of 'public participation'.

Generally, the users, sponsors, users or stakeholders tend to act within the dominant socio-technical paradigm, in foresight as much as any other policy process (Barre 2014): for example the GFIS above, seems to assume tacitly that 'experts' will know what to do with all the information received.

And yet if foresight is to have real significance it needs to include for alternative values and worldviews, problematic knowledge and inconvenient truths, for both the evidence and its applications. On the right of Figure $1 \mathrm{~A}$ we see a more open, multi-valent, inter-connected and cointelligent way of working with multiple domains, with equal priority for social, technical, political or 
cultural domains, worldviews and value systems. Also shown is a visualization of some of the different 'modes' of foresight, which are suitable for the different values / domains / worldviews above: visions, stories, images and models each have their own role to play.

\section{Foresight process}

Second is a question of 'process': a practical step-by-step method of enquiry and deliberation, suited to the challenge of cognitive complexity. To do this, the Synergy-Foresight method (i.e. 'Synergistic Foresight $3.0^{\prime}$ ) works in a " $4 S^{\prime}$ " cycle with four main stages, each with questions to be addressed, and each with practical methods and tools (see www.urban3.net/synergistics/) (Ravetz 2015). This is broadly similar to a six-stage model of foresight, with linkages to a five-stage policy cycle (Miles 2005 \& 2012): while the numbers can be discussed, the main point is the circular pattern of enquiry, intention and action. So in the linear / evolutionary model on the left of Figure 1B, the enquiry is generally focused, bounded and specific with its questions and priorities:

- System / baseline mapping stage: (questions - who / what is involved, what are their relations and connections??)

- Scenario / change mapping stage: (questions - what are the drivers of change, trends, tensions and alternatives??)

- Synergy / idea mapping stage: (questions - what are the possible synergies and opportunities, and who could realize them??). This stage shifts the focus of 'mapping' towards a focus on 'design', i.e. from analysis towards synthesis.

- Strategy / road-mapping stage: (questions - what to do next / soon / later: and who to do it??)

By contrast in the co-evolutionary process model on the right of Figure $1 \mathrm{~B}$, at each of the four stages there is a push towards the principles of synergistic co-intelligence. Here we can use a coordinated set of 'co' words. The 'system mapping' stage pushes towards collaborative 'co-learning', on the wider-deeper-longer model above. The 'scenario mapping' stage pushes towards collaborative thinking (i.e. 'co-thinking'), to look beyond immediate trends, towards bigger pictures of change and uncertainty. The third stage, 'synergy mapping', centres on co-creation and co-innovation for system transformation (Lee et al 2012). And the fourth 'strategy / road-mapping' stage looks at the implications for action, in co-production leading towards co-intelligence. Another way to frame similar notions is with the 'three horizons' which correspond roughly to three levels of coevolutionary change: linear change on a short term horizon: more strategic change on a second 
horizon: and beyond, wider and deeper transformations on a third horizon (Sharpe and Williams, 2013).

\section{INSERT Figure 1: Synergy Foresight subject and process}

\section{Foresight Agenda}

As above, the normative future is a crucial component of foresight thinking, and can be explored on the spectrum of preferred or desired or plausible futures (Ramirez and Stein 2014). Mapping a normative-future 'space of possibilities' (Figure 2A), shows some typical inter-connections of positive and negative, in both present and future. These 'cognitive agendas' are often tacitly assumed or in typical foresight methods, but as above, confusion easily breaks out. So the mapping here can help to see the process more clearly. The main types of linkage include:

a) 'Present negative with future positive': with baseline problems linked to long-term goals / aspirations, this is the typical 'Visioning' response to present day problems. Most of the case examples (next section) promoted this agenda, which clearly fits with civic boosterism, coalitions and populist politics (as seen in 2016 with the 'Brexit' Referendum).

b) 'Present / baseline median with future median': this is more exploratory and balanced, covering both positive and negative aspects of present and future, with ranges of uncertainty to suit the case (see the notes below on scenarios).

c) 'Present positive with future negative': or baseline assets and resources with future fears and dystopias. This is a kind of reverse visioning, the mainstay of dystopian film and fiction, which checks the apparent positive condition of the present against future risks, threats and catastrophic failures. In the UK city foresight experience, as in the next section, the growing threat climate change played this agenda, as a ghost at the feast of material plenty, which some listen to while others ignore.

d) 'Present positive with future positive': or, future utopias and aspirations with baseline assets and resources, as signals of positive connections between present and future. The current practice of strategic planning generally follows this agenda, stressing the present positives and the even greater future positives, as negative messages are seen to be politically risky and unpopular.

e) 'Present negative with future negative': or 'Future fears and dystopias' with 'Baseline problems and issues': these can be presented as signals or verifications of such fears, and 
might be pursued more by and academics and campaign groups who have an interest in the problem.

Overall this offers a rough mapping of a space of possibilities in normative futures (the diagram here is distilled from many flip-charts on work in progress in many foresight workshops). The mapping at Figure 2A shows again a linear / evolutionary model on the left side: here the 'future' is an image of the present: 'success' is a fixed target or 'winner takes all': and 'change mapping' is a projection of 'more/less of the same.

The co-evolutionary shift on the right hand side then points towards a synergistic model, where 'the future' is a transformation from the seeds of the present: 'success' is a vision for co-evolution: 'failure' is a missed turning on a longer journey. In practice, foresight participants often see such an inter-connected landscape, but struggle to articulate it in a small amount of time. Just sometimes, there is process 'emergence' - workshops which leave the rule book behind, which start buzzing with creative energy and vision, which point directly to the higher purpose of the foresight.

\section{Foresight object}

Lastly is the question of the 'object' of the foresight - what is the nature of the problem, system, or 'focal question' to be investigated? Here we draw on the synergistic method and its 'crystal table' visualization, as in Figure 2B. The crystal ball / spherical table is a crude image of a bundle of closely linked sub-systems with an overall metabolic effect. This can't represent every possible problem or issue, but from experience it is a useful way to start a mapping of grand challenges or wicked problems: for instance low-carbon cities, the 'war on drugs', or urban poverty (Ravetz, 2014). On the left side the 'object' is framed as linear, hierarchical, with a winner-takes-all competition: positive values are extracted by the elite: negative impacts are dumped and externalized. On the right, the 'object' system is co-learning, collaborative, co-creating and co-producing between all actors in all domains: positive outcomes are re-invested, negative impacts are internalized and there are many inter-connections between domains. This model brings great promise but also great challenge, with large 'aspiration' gaps or contradictions as highlighted by stakeholders.

For example, the 'One Planet' urban-regional foresights of 2004-2008, started with a 'trend-target' gap, represented by the carbon and ecological footprint trajectories. In hindsight this seemed to be a technical ' 1.0 ' framing of the 'object': in response, policy makers would construct scenarios on a 2.0 adaptive basis, while the citizens and the NGOS would visualize their aspirations for a more synergistic '3.0' model of society, and try to generate policy responses to match (Ravetz, 2006). In 
the Greater Manchester 2040 (next section), 'success' was visualized partly as a simple technical target (e.g. 'reduce inequality'), and partly as a co-evolutionary pathway (e.g. 'emergence of a sociopolitical paradigm in which inequality is reduced'). More generally there are typical tensions and gaps between the complex aspirations and tacit knowledge of stakeholders, and the need for 'rapid results' with 'indicators' and 'targets'.

\section{INSERT Figure 2: Foresight agenda and object}

To sum up so far, this is not to propose that a 3.0 model is 'better' or more advanced than 1.0-2.0 type foresight, as each has a role to play: rather that the 3.0 model may be suited to different kinds of problems, less linear and bounded, and more co-evolutionary and transformational. Another point is that the 3.0 model doesn't replace 1.0-2.0 versions, it would work better as a parallel and complementary layer.

In practice, urban problems and urban futures are complex and entangled (see the example of housing in Section 4). There is frequent confusion between the internal 'subject-process-object' structure, in that foresight 'subjects' are themselves part of the 'object' and part of the problem, and the 'process' is also dependent on both, and the 'agenda' is also politically driven by the 'subject', which then determines the scope and framing of the 'object'. And so on. The benefit of this kind of mapping is firstly to identify gaps and problems: e.g. where a 3.0 type sponsor is using the wrong method for a 1.0 or 2.0 kind of object. It can also help to identify opportunities: e.g. if the object and subject are clearly a technical 1.0-type frame, then we can go straight ahead: but if one or another are more like 2.0 or 3.0 models, then we can select the methods and tools more effectively. The mapping and visualization shown here aims at greater clarity, and so to more effective action. Table 1 shows a summary version of the 1-2-3.0 co-evolutionary framework, for each of the main foresight components.

\section{INSERT Table 1: Summary of co-evolutionary foresight components}

There is an important point on the parallel track of 'visual thinking'. The emergence and transformations above, each call for ways to look beyond conventional, rational, left-brain type 
thinking on a techno-economic axis. We need to consider a range of channels and media to enable better connections with other dimensions of human experience. Visual thinking is not the only way, but it can fit easily with text and rational style thinking and policy processes, and so is strongly recommended for any foresight which aims at more than a 1.0 model (Ravetz, 2011 and 2013). Figure 3 shows a visual example of the transition from linear to co-evolutionary thinking in the Synergy Foresight approach.

\section{INSERT: Figure 3: Synergy Foresight: a visual thinking perspective}

\section{Normative futures and boundary issues}

Cities are a visible example of a boundary problem, not only in physical boundaries but in chains of cause and effect, where the 'policy space' are matters of debate and controversy. For example, questions come up on the local response to climate change, versus global context: are cities just passive victims of policies from higher levels: or can they mobilize creative thinking and opportunities at the local level: and what kind of transformations would be needed to do this? This is a fundamental question for those at the city level, for instance on low carbon policy (Bulkeley \& Betsill, 2003). Such questions can be made more visible, by mapping different scenario types across the co-evolutionary framework:

- linear type (1.0) scenarios: these are basically context, with different trajectories and few inter-connections, with each other or with the normative. For example a 'low carbon 1.0' scenario assumes climate change, technology, economic and political failures.

- adaptive type (2.0) scenarios: these are more about the 'biological' dynamics of competition or adaptation. Then, variations can be explored to make the best of a negative situation, or increase the chances of the positive. For example a 'low carbon 2.0' scenario looks for business opportunities which might change the assumptions of a 1.0 type projection.

- synergistic type (3.0) scenarios: these centre on a more pro-active human agency, and its inter-connections with the context, and the pathways needed to realize the normative goals. For example: a 'low carbon 3.0' scenario explores the scope for learning, collaboration and shared intelligence, to manage the negative effects and widen the positive.

This mapping also helps to bring into focus the normative, as pictured in Figure 2A. There are many variations on normative visioning, priority choice, 'success scenarios', back-casting, and so on 
(Bezold, 2009). There are common features, in that they aim to define through social processes of deliberation or actualization, a desired collective future, and then to explore ways to achieve it. In practice it's not so difficult to generate normative visions and aspirations: the greater challenge is then to connect them back to current realities. Again there are gaps and dissonances which show up in the scenario components of the city foresights in the next section. A linear (1.0) model of normative 'success' has a frame of 'more of the same', higher GDP growth, larger houses and cars, more shopping and so on. An evolutionary (2.0) model of normative 'success' is more about dynamic conditions or spaces of possibility, e.g. more room for entrepreneurs to succeed, or more chances for communities to innovate. In contrast a co-evolutionary (3.0) model of normative 'success' is more aspirational and often more fuzzy, pointing towards a synergistic society in social, technical, economic or ecological transformation. A good example comes from the 'Generation 2040' component of the Greater Manchester 2040 project: students of age 17-19 were very clear in their aspiration for connected communities, inclusive societies, and a human-centred education system, each being a powerful and normative, transformative agenda (see www.gm2040.com/about).

\section{Applications to city level foresight}

The question is, if cities need foresight thinking as they seem to, why does it so often seem problematic, controversial, and falling short of aspirations? We could start with the variety of frames for mappings of urban systems. Some are focused on a city as a hub in a global system, with flows of finance, energy, and knowledge. Others are focused on what happens inside: production systems, infrastructure and built environment, social and cultural dimensions. So it may be the 'text book model' of fully-fledged urban foresight, focused on urban issues with a long term horizon, including stakeholder participation, and informing rational and evidence-based strategic planning and policy, is quite rare. Brave attempts such as the Georgia Basin Futures Project in Canada, brought to the surface all the typical conflicts and tensions between sponsors, researchers and participants (Robinson \& Tansey, 2006). The recent case of the UK Foresight on Future of Cities is an example of a large expert-driven programme, set against a volatile and politically driven policy context, with its final results delayed and (at the time of writing) seemingly unlikely to make a full contribution to the policy process. 


\section{Boundary issues and tensions}

One source of tension is that of 'boundaries' and 'horizons'. For longer term studies (30+ years), the rate of change (structural or paradigm change) - is generally greater than the degree of system stability and coherence. So in technical terms we can't build a model of the system, and we can't trust the existing models: even the concepts behind the models, are suspect beyond 5 years let alone 30. And yet, decisions on infrastructure investment and spatial development are very likely to have long term effects of 30-100+ years. Who might use a urban foresight with $30+$ year horizons, and why? For those looking at wider definitions of 'value' and public investment, urban infrastructure will be around for 30-100 years (extending from past trends), but will be fully financed within 20-30 years: therefore the 30-100 year period is more concerned with 'social cultural or ecological value', in the more qualitative area of vision, aspiration, agenda setting etc. So we can gather participants for a long term foresight, but it may not be well connected to real-time investment or policy decisions.

For urban spatial horizons, the conventional definitions of 'the city' aren't always well connected to the reality. Many concepts of the 'urban' are shifting towards the 'global urban system' or 'regional' / 'territorial' ... (and in many cases including 'rural'). It could be argued that the focus on the conventional 'city' (assuming this as a clear specific thing), is actually misleading, if it distracts attention from other significant levels of spatial activity: the peri-urban, metro-scape, tax-haven enclave, 'aerotropolis', and so on (Piorr et al, 2011).

In technical terms, why is the 'urban' system less modelled and analysed than others such as energy and emissions? It could be that energy is more focused on its core technical systems which are more 'tractable': so when an energy study looks at fuzzy, controversial, socio-political issues, it can still build on solid foundations in physics and engineering. In contrast, there are many attempts at a 'science of cities', focused on physical systems of landuse, buildings and infrastructure (Batty, 2014): but these tend to downplay other qualities and transition effects, such as social-cultural change, work-home relationships, community-household, lifestyle-network, and so on. For such qualitative relational systems shaped by human cognition and collaboration, technical modelling needs better connections with other methods, which are more suited to 'cognitive-collaborative-complexity' and the synergistic approach (Ravetz, in press).

\section{Urban policy and sectoral applications:}

Urban systems are subsets of national / global systems, often picking up problems caused at other levels: so there are issues of agency, displacement, split incentives etc. But this raises political and ethical questions. For instance, the current response to the credit crunch / financial deficit in the UK 
and similar countries, creates problems of poverty, unemployment, homelessness, ethnic conflict etc, which are often magnified or at least more visible in cities. But urban policy-makers in turn have increased financial pressures and reduced powers to respond. Many urban foresight projects put the problem of 'poverty' in a box alongside 'transport' or others, and then focus only on the boxes where there is a realistic chance of local success. Again there is huge potential for a more interconnected approach.

However this would then raise the challenge of critical perspectives, conflict and dissonance: where clearly, many cities are arenas for social movements, protest and challenge. The dominant ideologies of neo-liberalism, globalized finance, centre-right small state, tend to create more 'losers' alongside 'winners': but the (apparently) techno-economic rational worldview often pushes this to the side. For instance, the UK 'Land-use Futures' foresight produced a wide-ranging science-policy review: but (in the published version) omitted a rather crucial point, that $80 \%$ of land is owned by $3 \%$ of the population (Foresight Land Use Futures Project, 2010: Cahill, 2002). As cities are increasingly fragmented and polarized, this calls for a new generation of Synergy Foresights, which start from the reality of conflict and contradiction, and find pathways through and beyond.

Similar questions apply for each of the main urban policy sectors. We can identify the sectors most involved with the long-term strategic approach: demographics, spatial planning, housing and community, urban infrastructure, public services, environment and ecosystems, and so on. Table 2 shows a summary of the co-evolutionary 1-2-3.0 perspective on 'strategic urban intelligence' for each sector, which were variously taken up in the case studies to follow.

\section{Table 2: Application to strategic urban intelligence}

Cities can also learn from innovations at national or global levels: for instance the Millennium Project "Global Futures Intelligence System" aims in a similar direction (www.millennium-project.org), and offers new methods of participation, such as the Real Time Delphi System (Gordon, 2012). One practical example is the Finland 'Urban Zone' project: this collects spatial data and urban trend projections for every local / regional authority in the country, and puts them on a common platform, as a common resource for a foresight-type program of exchange, learning, deliberation and strategic planning (Newman et al, 2015). This and many other examples point to the creative diversification of foresight-related activities in city governance. 


\title{
3. UK FORESIGHT ON FUTURE OF CITIES
}

\author{
This section reviews experience from the Future of Cities Network, which worked 2014-2015 with \\ parallel projects in Greater Manchester (GM), Newcastle, Liverpool, Cardiff, Reading. In the \\ background was a wider set of 22 'City Visions' projects with at least some foresight or futures \\ components. Both were sponsored as part of the national UK Future of Cities programme, run by \\ the Foresight Unit at the Government Office of Science, with details on \\ https://futureofcities.blog.gov.uk/. The aim here is not a comprehensive report on the national \\ programme, but a brief outline of four city projects, to illustrate the methods and point towards \\ future opportunities.
}

\section{Greater Manchester 2040}

With funding from Government Office for Science (GOS) and the Greater Manchester (GM) Local Enterprise Partnership, the 'GM2040+' (Greater Manchester 2040) project was run by the agency New Economy with the Institute of Innovation Research at the University of Manchester. The project centred on a 'success scenario' workshop in late 2014, together with desk study and stakeholder dialogue before and after. All materials are available on www.gm2040.com . Some very topical policy initiatives came up during the course of the project. In late 2014, 'DevoManc' set up the devolution of substantial powers to the Greater Manchester ('GM') Combined Authority. Then in early 2015, the 'Devo-Health' agreement proposed that the entire NHS budget within GM be devolved and run locally, with huge implications for services and governance. On a fast moving picture, the foresight was developed with standard futures methods, with a focus on the aspirational side through a 'success scenario', which aimed to contribute directly to the 'Devo-Manc' policy process. Alongside the workshop there were various studies and consultations, including -

- drivers of change, drawn from the UK project, developed by expert consultation, tested with an online stakeholder survey; 
- alternative future scenarios, adapted from other research-policy projects, including the periurbanization project 'PLUREL', which in turn referred to the 'special report on emissions scenarios' of the IPCC (Ravetz and Warhurst 2013);

- other recent futures / foresight type exercises in GM and the various policy organizations which have flourished there;

- Consultations on the application of the scenarios to 'transitions' and 'pathways' in key sectors including energy, transport, housing;

- Visual thinking was a continuing strand through the project as above;

- A spin-off project 'Generation 2040' involved young people at the local college, and contributed a powerful statement of aspiration, as above.

With a range of future drivers and possibilities on the table, the main questions emerged: what were the collective 'ambitions' of GM? And how, in the face of uncertainty and challenge, could they be achieved? For this a 'success scenario' was co-produced, to explore what is 'preferable and plausible' for the wider community of GM. The final step was to look for the bigger picture: to test the ambitions against uncertainties and challenges, and map out strategic 'pathways' towards success, as directions of travel, opportunity and synergies. These pathways bring to the surface some underlying qualities, as in Section 2: resilience by community co-production: creative policy coinnovation: social co-learning and collaboration: anticipatory collaborative governance, and general urban policy co-intelligence.

The implication is that, whichever way the 'Devo' agenda goes, GM has great potential to be a leader among world cities of its size, in many areas that create community, cultural, economic and environmental prosperity and well-being. The success scenario method focused on the benchmarking of GM against the UK and the world, which seemed quite effective with stakeholders. However GM also has massive challenges, in the legacy of early industrialisation and deindustrialisation, and in the highly skewed development of the UK space. Beyond the prosperous core, GM struggles with inequality and dependency, low skills and productivity, poor quality built environments, and in the near future the impacts of climate change. The current GM 'Devo' agenda offers many opportunities, but also risks, in the context of shrinking resources, organizational flux, and a current lack of integration and co- intelligence. Unfortunately in practice the foresight programme happened to coincide with the launch of Devo-Manc in 2014, as a policy and programme, at the centre of the so-called 'northern powerhouse': the net effect was that the attention of most policy-makers was on a very fast moving present rather than any strategic future. Overall the messages from the foresight were that GM could and should do more in strategic 
thinking and co-intelligence, with a more embedded and continuous foresight program, generating strategic linkages into policy, business and civil society.

\section{Newcastle City Futures}

Here the civic agenda starts with the city's peripheral location, with high levels of dependency and vulnerability of the regional economy. City-region collaboration between neighbouring authorities is not simple, however there are close bonds and a very effective 'triple helix' ecosystem within the city itself.

Newcastle City Futures examines significant architectural and planning projects that have shaped and reshaped the city in the latter half of the 20th century and continue to do so in the 21st century. There was positive cross-sector collaboration in a city which is focused on modernity and change, and the result was an exemplary programme of events including an exhibition, public forums, educational initiatives and sector studies, jointly hosted by Newcastle University and its partners, as on www.newcastlecityfutures.org . The overall aim was to start a 'big city conversation' and engage all sectors in debates about the city's future (Tewdwr-Jones, 2014).

A year on from this initiative, questions can be raised on the overall effect and value added. It seems well received as a civic contribution: however the results then feed into a real-time and more complex game, of access to external funding, landholdings and development prospects, changing government policy on 'City Deals' and devolution, and general strategies for survival in an age of harsh austerity.

\section{Cardiff 2050:}

Issues in Cardiff start with urban regeneration and the effects of gentrification: and the city's role as the capital of Wales, a partly autonomous 'devolved administration', with strong national culture and weak national politics. There are familiar urban problems of growth and congestion, alongside post-industrial restructuring, inequality and dependency, with much deprivation concentrated in the Valleys to the north of the city. However Cardiff and its region have a visible commitment to sustainable development and a low carbon / One Planet future (Ravetz, 2007): and the Welsh Assembly Government's recent Bill on 'sustainable development' is one of the most advanced anywhere. 
Cardiff 2050 was part of the national research programme 'Retrofit 2050' (Eames et al 2014). It sets out three alternative scenarios for long term visions for urban sustainability, covering the wider cityregion beyond the urban area. 'Connected Cardiff sees a hi-tech distributed city-region with excellent transport and communications: 'Compact Cardiff' sees a dense, mixed use, liveable urban structure: and 'Orchard Cardiff' sees local food, biodiversity and climate adaptation. There is some expert analysis of the transition pathways, spatial implications, and policy implications. There was a series of stakeholder workshops, but it's not clear how far these were embedded and mobilized in mainstream structures.

\section{Reading 2050:}

The city of Reading, a major hub on the west side of Greater London, is one of the most prosperous in the UK, with strengths in hi-tech and digital industries, innovation and inward investment. The urban issues here are more about growth and congestion: urban containment and quality of life, and growing inequalities in the urban system.

The 2050 Reading City Vision project was a collaboration between the UK's largest design and planning consultancy and the university. 'Creating a smart and sustainable future for Reading 2050' centred on a major futures workshop with a three-stage scenario planning method: developing the vision: pathways for the vision: and implications for urban design. The process focused on cocreation of three parallel scenarios, similar to those of Cardiff: a smart networked city: compact city: self-reliant green city (Dixon and Cohen, 2015).It seems (at the time of writing) that this programme was successfully integrated into Reading's strategic planning and related activities.

\section{Implications of the city demonstrations}

Each of these four examples has focused on the 'city vision', as a co-created common concept, with the aspiration to uniting different sections in the city system. Applying the co-evolutionary framework and the foresight dimensions from Section 2, some key questions come up with implications for ways forward:

a) How to bridge the gap between 'vision' and 'strategy' or implementation? This assumes that the 'vision' is developed in a neutral space, where benign authorities have an open mind, evidence, resources, skills and capacity for participation - conditions which are rare in practice. We could turn the question around - how to connect strategy (housing, transport, infrastructure etc), with the visions which emerge from civil society? This involves the 
'subject co-evolution' strand of our framework: i.e. where the sponsors / agents / providers / users of the foresight are themselves co-evolving, co-learning, co-processing and cocreating capacity for an urban co-intelligence .

b) How to resolve competing visions? For example, GM centred on one success scenario, where (arguably) underlying tensions were not resolved. Newcastle focused more on local practical visions for actual sites and infrastructure. Reading and Cardiff used alternative scenarios on the positive aspiration side, but said little about negative forces. This is a challenge for the 'process co-evolution' strand of the framework: i.e. where the foresight method needs to find ways of exploring and managing structural problems, controversies, dilemmas and hard choices.

c) How to focus the vision on structural change and reform? The Manchester case for instance, raised the challenges of inequalities, alienation, fragmentation etc: but was not able within the foresight, to follow up the debate or mobilize action in any meaningful way. This is a challenge for the 'agenda co-evolution' strand of the framework: i.e. that to mobilize the vision involves co-evolutionary change in the wider urban economy, society, infrastructure, and spatial form.

d) How to frame the urban system in a way which is relevant to the challenge of transformation? This concerns the 'object co-evolution' dimension of the foresight programmes. The example below of energy housing retrofit comes up in each of the four case studies: if the housing stock is framed as a linear 'numbers of units' question, the means of transformation are off-model externalities. If the housing stock is framed as a cognitive-collaborative-co-learning question, then extended deliberation is needed, for which resources are likely to be scarce. This need for continuous and extended deliberation points toward the next section, and the implications for a City Foresight Platform.

\section{WAYS FORWARD:}

\section{Towards a City Foresight Platform}

In almost every urban foresight exercise there is a common response from participants, that the information is all fragmented: that simple policies don't work with complex needs: that government 
silos produce short term fixes. This suggests the benefit of applying the co-evolutionary framework outlined above, for some practical ways forward.

For this we put up a proposition for 'the possibility of a City Foresight Platform'. We envisage this on two main tracks: a human system of co-learning and collaboration, and a technical system of information management and exchange. Such a 'platform', 'hub, exchange or network, would aim to promote and support 'strategic policy intelligence', at the local / city / region scale. As a continuous resource library and deliberation programme, it would also enable one-off major enquiries on the foresight model. Overall it would provide a kind of arena for co-intelligence and strategic 'anticipatory governance', which can take a forward look, mobilize the resources of all actors, and respond better to complex problems.

There are many possible approaches and platform models, in a fast developing field, as described by others (Konig and Evans, 2013: Hendriks, 2012). Here the aim is to identify some fundamental principles for the scope and potential of such a platform, and the synergistic method is a useful guide to looking beyond conventional boundaries:

- 'wider', with inter-connections of actors: with ways to bring together and generate collaborative action between different groups and organizations, sectors and supply chains. Example models are the 'triple helix', civic university, urban forums, urban rooms, living labs, open data platforms:

- 'deeper', with integration of alternative domains and value systems: we look for linking actions between value systems: e.g. social, technical, economic, environmental, political, or cultural. Examples include café scientifique, city visions, community design and similar.

- 'longer' horizons of change and transformation: from direct short term trend projections, towards medium term evolution of markets or policies, all the way to a longer term coevolutionary transformation of whole socio-technical systems.

To mobilize these synergies needs enablers, creative spaces, catalysts, inter-mediaries, boundaryspanners, civic entrepreneurs, cultural ambassadors, or other 'change agents'. Such enablers will encourage inter-connections of many kinds: innovation, experimentation, prototyping, visioning, design thinking and so on. The City Foresight Platform can play the role of a laboratory, arena, forum, hub, exchange, incubator, or 'sand-pit'. In each there are opportunities to enable ideas and collaborations and synergies and prototypes, in order to grow, emerge, develop, cultivate, flourish, adapt or reproduce. 
Many such laboratories or platforms exist in many places, but now we are looking to step up a gear. We can look beyond the 'inter-connections of things', as in current versions of Living Labs, City Labs or Futures Labs. We can look towards a Platform model which is more about the 'inter-connections of thinking', for a more co-evolutionary kind of social learning and synergistic collaboration.

The Platform's futures perspective stretches from the citizen visions and aspirations, to technical modelling and forecasting. We find that 'the future' is most interesting when it's challenging and controversial: visions can explore the cracks and contradictions in ideologies: system models should aim to demonstrate what we don't know: and technical forecasts can explore uncertainties. Where short term change and turbulence reduces 'the future' to just a few months (as in the UK in 2016), the Platform adjusts its focus to a shorter term resilience and resources to manage change.

The Platform's technology sees the potential transformation, from a Web 2.0 system of interactive flows towards a next generation semantic Web 3.0 of intelligent relationships. This brings huge possibilities: artificial intelligence in many forms, text mining with sentiment analysis, crowd-sourced collaboration, internet-of-things monitoring, or complex predictive modeling (Shroff, 2013). And for the Platform's social processes, a 'design thinking' approach follows the principles on 'deliberative, inclusive, participatory' processes to respond to complex inter-connected problems. We avoid conventional meetings where experts give powerpoints to rows of chairs: rather we look towards methods such as open-source ideas, community visioning, indabas, un-conferencing, goldfish bowls, appraisal / mapping toolkits or round table foresights, which provide more creative spaces for synergistic deliberation.

At the time of writing a prototype platform is being developed in partnership with the GM policymakers, as a follow-on to the GM2040 programme. This is an application of the GM Devolution programme, and aims to demonstrate a 'triple helix' collaboration between public, private and academic sectors. It calls for improved capacity in foresight and the 'urban co-intelligence' capacity for co-learning and co-innovation between all parts of society (Figure 4).

\section{INSERT Figure 4: City Foresight Platform demonstration model}

The Mini-Lab is an innovative partnership between the University of Manchester and the Greater Manchester Low Carbon Hub. The overall aim is to demonstrate a prototype 'triple helix' model of urban innovation model, in the cluster of 'low carbon retrofit for inclusive growth', drawing on the RSA programme on 'inclusive growth' (RSA 2016). There are three main objectives: to contribute to 
the urban co-intelligence and capacity for co-learning and co-creation: identify practical researchpolicy links in this cluster: evaluate the prototype with lessons for wider dissemination. This cluster includes a series of inter-connected topics: economic development: housing retrofit: energy efficiency: fuel poverty: public health: Devolution policies: housing markets: green infrastructure: quality of life and social inclusion.

The Methodology of the Mini-Lab is based on the 'synergistic toolkit' as in Section 2, for mapping of complex systems in co-evolution (Figure 4). It contains are two main 'platforms' in parallel. Firstly a 'social platform', with a triple / multi-helix of stakeholders, knowledge exchange for co-learning and co-production. In parallel is an 'evidence platform', a resource base and interface for policy documents, academic material, and spatial analysis (linked to the inhouse facility at www. mappinggm.org.uk). This online platform uses the knowledge management system 'Compendium', which enables multiple forms of content, with a range of analytics and visualizations of concepts, arguments, discourses and dialogues.

The process model then follows the synergistic foresight cycle. Firstly, baseline analysis of the present situation: second, 'change mapping' of drivers and dynamics: third, future synergies and innovations: fourth, a pathway and road-mapping for strategy and action. Within the Low-CarbInclusive-Growth cluster a shortlist of priorities will be selected for the demonstration, each with social and technical items: and each with material on baselines, changes, innovations and pathways.

The academic benefits and outcomes include: enhanced knowledge exchange, research collaboration, civic engagement, and leadership on a unique innovation with wide applications. The policy and civic outcomes to the GM partners include firstly, practical contributions to the 'LowCarbon Inclusive Growth' cluster: and second, strategic contribution to 'urban intelligence' and 'urban co-innovation'. This focuses on three main areas: policy innovation for organizational learning and policy coalitions: financial innovation especially for realizing social values and overcoming market failures; social innovation for mobilizing social enterprise and community development.

With this a range of transformations and game-changers can be explored. One example is that of a city-region-wide integrated low-carbon housing retrofit system. This demonstrates the scope of multi-scalar, multi-sectoral working, on an issue of national significance. It might appear simple in principle to retrofit the housing stock, but in practice there is a minefield of perverse incentives, unintended consequences and moral hazards, in which the housing market is a kind of casino for national and global players (Bouzarovski 2016: Shrubsole et al 2014). So there is a real value in 
exploring a range of frames and paradigm models, from linear to evolutionary and co-evolutionary. This is currently taking shape as work in progress, as follows:

- Linear model ('Retrofit 1.0'): low-carbon retrofit is mainly focused on numbers of housing units, megawatts and tonnes of carbon, or measures of poverty and deprivation.

- Evolutionary model ('Retrofit 2.0'): low-carbon retrofit is focused on the operation of the market with incentives and surpluses, barriers or failures. It also looks at behavior change, policy analysis, professional roles, industry supply chains and so on, with insights from the evolutionary social sciences.

- Co-evolutionary model ('Retrofit 3.0): low carbon retrofit mapping and analysis takes all the above on board, and then looks at the potential for co-learning, co-processing, co-creation and co-production, in bridging institutional gaps and market failures. Markets in housing or energy are not assumed to be autonomous invisible-hand processes, but more like reflexive, learning, collaborative and deliberative entities. Likewise the policy process and social process opportunities revolve around urban co-intelligence and energy co-intelligence, with full range of inter-connections to related issues such as poverty and the welfare system, construction and skills, infrastructure and spatial planning, social innovation and behavior change.

\section{CONCLUSIONS}

This paper draws from personal experience of foresight processes at the city or city-region level. We present an outline framework and methodology which has emerged from this experience, with wide applications. We review the recent experience in the UK Foresight for Future of Cities: explore the scope and 'possibility of a City Foresight Platform': and sketch a current prototype in Greater Manchester as work in progress. Overall there are no forecasts or guaranteed models. We live in an age of flux and uncertainty, where many assumptions are giving way, with systemic transformations in urban economies, communities, governments, technologies and cultures. At the same time, we're in an age of crunches and crisis points and 'grand societal challenges': cities are the locus for conflict, within and between local and global: on environment and climate, cultural differences, social inequalities or financial vulnerabilities. 
So the idea of shared learning, collaboration, synergy and intelligence is powerful and urgent: but not necessarily as we have known it. Whole libraries of books on cities contain few clear 'answers'. In contrast we need to look for more dynamic processes, value-driven and entrepreneurial on both micro and macro scales. In this the role of foresight can be crucial. Again we look beyond traditional 'BOGSAT' ('bunch of guys sat around a table') models of foresight, towards something which is more fluid, responsive, reflexive, networked and open-ended. In this it could aim to ride some of the current waves: social technology, economic co-production, eco-cultural enterprise, participatory public services, open source governance, and so on. In conclusion there is a tremendous space of opportunities for cities and the contribution of foresight practices. 
REFERENCES

Ackoff, R, (1973), Science in the Systems Age: Beyond IE, OR, and MS, Operations Research 21(3), pp. $661-671$.

Atlee, T, (2003) The Tao of Democracy: Using Co-Intelligence to Create a World That Works for All : The Writers' Collective, Cranston, RI

Barré, R, (2014): Innovation system dynamics and the positioning of Europe. A review and critique of recent Foresight studies. Foresight, Vol.16(2):126-141

Bar-Yam, Y, (1997) Dynamics of Complex Systems: Addison-Wesley, Boston, MA

Batty, M, (2014): The new science of cities, Boston, MIT Press

Beer, S, (1966), Decision and Control, Wiley, London

Bezold, C. (2009). Aspirational futures. Journal of Futures Studies, 13(4), 81-90.

Bouzarovski, S, (2015) Retrofitting the City: Residential Flexibility, Resilience and the Built Environment: London, I.B.Tauris

Brand, R. (2005) Synchronizing Science and Technology with Human Behaviour. Earthscan, London Buckley, W.F. (1998): Society-- a complex adaptive system: essays in social theory: Gordon and Breach, Amsterdam

Bulkeley, H. \& Betsill, M.M. (2003). Cities and Climate Change: Urban Sustainability and Global Environmental Governance. Routledge, NY.

Cahill, K (2002): Who Owns Britain? London, Canongate Books

Checkland, P \& Scholes, J, 1990: 'Soft Systems Methodology in Practice': Wiley, Chichester

Clayton, A, Radcliffe, N, 1996: 'Sustainability: a systems approach': Earthscan, London

Cohen, M.A. (2012): Reinventing the Future: Designing Urban 3.0: Harvard International Review, Summer 2012, Vol. 34 Issue 1, p52-57

CoR (Committee of the Regions) (2011) An initial assessment of territorial forward planning/foresight projects in the European Union. Brussels, CoR

DG REGIO (2011): Cities of Tomorrow: Luxembourg, EC publications

Dixon, T and Cohen, K (2015): Towards a smart and sustainable Reading 2050 vision: Town \& Country Planning, Vol.84(1):pp26-33 
Eames, M., De Laurentis, C., Hunt, M., Lannon, S. and Dixon, T., (2014) Cardiff 2050: City regional scenarios for urban sustainability. Project Report. Cardiff University, Cardiff. Available at: http://www.retrofit2050.org.uk/cardiff-2050-city-regional-scenarios-urban-sustainability (part of the Retrofit 2050 project, funded by the EPSRC, grant number EP/I002162/1).

Eerola, A, and Miles, I, (2011)“Methods and tools contributing to FTA: A knowledge-based perspective" Futures Volume 43, n³, (April) pp 265-278

Espinosa and Walker, (2011). A complexity approach to sustainability: Theory and applications. Fernandez-Guell, J.M, and Redondo, L, (2012) Linking territorial foresight and urban planning: Foresight, Vol.14(4):316-335

Folke C., J. Colding, and F. Berkes, 2002. Building resilience for adaptive capacity in social-ecological systems. In: Berkes F., J. Colding, and C. Folke (eds). Navigating Social-Ecological Systems: Building Resilience for Complexity and Change. Cambridge University Press, Cambridge, UK.

Foresight Land Use Futures Project, (2010): Land Use Futures: Making the most of land in the 21st century: Final Project Report. London, Government Office for Science.

Fish, R., Burgess, J., Chilvers, J. Footitt, A., Haines-Young, R. Russel, D., Winter, D.M. (2011) Participatory and Deliberative Techniques to embed an Ecosystems Approach into Decision Making: an introductory Guide. (Defra Project Code: NR0124)

Funtowicz, S., Ravetz, J., (1994) Emergent complex systems. Futures 26 (6), 568-582.

Geels, F.W., (2004), From sectoral systems of innovation to socio-technical systems: Insights about dynamics and change from sociology and institutional theory: Research Policy 33:897-920

Gordon, T.J, (2012) The Real-Time Delphi Method: In: Glenn, J.C. (Ed) Futures Research Methodology V3.0. Millennium Project

Hamilton, M. (2008). Integral City: Evolutionary Intelligences for the Human Hive. San Francisco, Island Press

Hendriks, F., (2014) Understanding Good Urban Governance: Essentials, Shifts, and Values. Urban Affairs Review, vol. 50: 4, 553-576.

Holland, J.H,(1998), Emergence: From Chaos to Order. Addison Wesley, NY Inayatullah, S, 2011: City futures in transformation: Emerging issues and case studies: Futures 43 (2011) 654-661 
König, A. and Evans, J. (2013) “Experimenting for sustainable development? Living laboratories, social learning, and the role of the university," In: König, A. (ed.) Regenerative sustainable development of universities and cities: the role of living laboratories, Edward Elgar. 1-24

Leach M, Scoones, I and Stirling, A (2010) Dynamic Sustainabilities: Technology, Environment, Social Justice, London: Earthscan

Lee S.M., Olson, D.L, Trimi, S, (2012) "Co-innovation: convergenomics, collaboration, and co-creation for organizational values", Management Decision, Vol. 50 Iss: 5, pp.817 - 831

Loveridge, D, (2009): Foresight: The Art and Science of Anticipating the Future: Taylor \& Francis, Abingdon

Meadows, D.H. (2008). Thinking in systems : a primer. Earthscan, London

Miedzinski, M, (2015): Public policy for long-term societal challenges? The reframing of policy narratives and the 'Roadmap to a Resource Efficient Europe': Phd Thesis, John Rylands Library, University of Manchester.

Miles, I, Saritas, O and Sokolov, A, 2016, Foresight for Science, Technology and Innovation, Berlinm Springer

Miles, I. (2012) “Dynamic Foresight Evaluation", Foresight vol. 14 Issue 1, pp.69-8

Miles, I, (2010), "The Development of Technology Foresight: A Review", Technological Forecasting and Social Change Vol 77 issue 9 pp1448-1456

Moran, M, and Williams, K, (2015): 'Devo Manc': 'Northern Powerhouse' or 'Northern Poorhouse'?: Open Democracy: www.opendemocracy.net/ourkingdom/mick-moran-and-karelwilliams/\%27devo-manc\%27-\%27northern-powerhouse\%27-or-\%27northern-poorhouse\%27 Mulgan, G, (2014) 'True Collective Intelligence: a sketch of a new field', Philosophy and Technology, 2014 27:122-133

Nevens, F., N. Frantzeskaki, L. Gorissen and D. Loorbach: (2013): 'Urban Transition Labs: co-creating transformative action for sustainable cities': Journal of Cleaner Production, Vol. 50:111-22

Piorr A, Ravetz, J, Tosics I, (2011), Peri-urbanisation in Europe: Towards a European Policy to Sustain Urban-Rural Futures: (Synthesis report of the PLUREL project): Luxembourg, European Commission. http://www.plurel.net/Synthesis report Peri-urbani -sation in Europe-115.aspx (accessed May 2015) 
Ramirez, R and Stein, C (2014): Plausibility and probability in scenario planning. Foresight 16(1): 5474

Ravetz, J, (2000): 'City-Region 2020: integrated planning for a sustainable environment': (with foreword by the UK Secretary of State for the Environment), London, Earthscan with the Town \& Country Planning Association

Ravetz, J, (2006) “Regional innovation \& resource productivity - new approaches to analysis and communication" In: Randles S \& Green K (Eds) Industrial ecology \& spaces of innovation: Edward Elgar, London

Ravetz, J, (2011): Exploring creative cities for sustainability with deliberative visualization: In Girard, L.F. and Nijkamp, P (Eds): Creativity and Sustainable Cities: Oxford, Heinemann

Ravetz, J, (2013): Beyond the linear: the role of visual thinking and visualization, In: O'Riordan, T and Lenton, T, (Eds): Addressing Tipping Points for a Precarious Future: Oxford University Press for the British Academy: pp289-299

Ravetz, J \& Warhurst, P (2013): Towards the new local-global: the emerging peri-urban of the Manchester city-region: In: Pauleit, S., Bell, S., and Aalbers, C., (eds), Peri-Urban Futures: Land Use and Sustainability, Berlin: Springer.

Ravetz, J, (2014): Inter-connected responses for inter-connected problems: synergistic thinking for local urban development in a global urban system: International Journal of Global Environmental Issues, special issue on local economic development. Vol. 13(2/3/4):362-388

http://www.inderscience.com/info/inarticle.php?artid=64506

Ravetz, J, (2015): The Future of the Urban Environment \& Ecosystem Services in the UK: (Working Paper 16 for the Foresight Future of Cities): London, Government Office of Science.

https://www.gov.uk/government/collections/future-of-cities

Ravetz, J, (forthcoming,) City 3.0: pathways from smart to wise. London, Routledge / Earthscan: Ringland, G (2002): Scenarios in public policy: Chichester, Wiley

Rittel, H, and Webber, M (1973); "Dilemmas in a General Theory of Planning," pp. 155-169, Policy Sciences, Vol. 4, Elsevier Scientific Publishing Company, Inc., Amsterdam, 1973.

Robinson, J, \& Tansey, J, (2006): Co-production, emergent properties and strong interactive social research: the Georgia Basin Futures Project. Science and Public Policy, vol.33(2):151-160, RSA (Royal Society of Arts), 2016: Inclusive Growth Commission: Prospectus of Inquiry: London, RSA 
Sharpe, W, and Williams, J (2013): Three Horizons: The Patterning of Hope: Edinburgh, Triarchy Press.

Shroff, G (2013). The Intelligent Web: Search, smart algorithms, and big data: Oxford, Oxford University Press

Shrubsole, C, Macmillan, A, Davies, M and May, N (2014). 100 Unintended consequences of policies to improve the energy efficiency of the UK housing stock. Indoor and Built Environment.

Strategy Unit, (2001): Understanding Best Practice in Strategic Futures Work: London, PMSU Stuckler, D and Basu, S (2013) The Body Economic \& Why Austerity Kills: Recessions, budget battles and the politics of life and death: NY, Basic Books TCPA (Town and Country Planning Association) (2015): The Future of Planning and Place-Making. London, TCPA

Tewdwr-Jones, M., A. Fry, E. Coffield, D. Sookhoo and D. Mitchell: (2014): 'A room within the city - a place for dialogue and planning imagination'. Town \& Country Planning, Vol.83(9):372-379 Tomaney, J and McCarthy, A (2015): The 'Manchester Model'. Town \& Country Planning, vol. 84(5):233-237

van der Sluijs, J.P., van Est, R., Riphagen, M., (2010) Beyond consensus: reflections from a democratic perspective on the interaction between climate politics and science, Current Opinion in Environmental Sustainability 2, 409-415, Waltner-Toews, D, with Kay, J and Lister, N (2009): The Ecosystem Approach: Complexity, Uncertainty and Managing for Sustainability: Columbia University Press, NY Wong, C, Baker, M, Hincks, S, Schulze-Bäing, A, Webb, B (2012) A Map For England: Spatial expression of government policies and programmes: Final Report to The Royal Town Planning Institute. London, RTPI. Yang, A and Shan, Y (2008) Intelligent Complex Adaptive Systems: IGI Publishing, Hershey, PA

\section{Acknowledgement:}

The authors would like to acknowledge the support of the UK Government Office of Science 'Foresight on the Future of Cities' programme, for the initiatives on the Future of Cities Academic Network, and the Greater Manchester 2040. Ian Miles' contribution to this article was prepared within the framework of the Basic Research Program at the National Research University Higher 
School of Economics and supported within the framework of a subsidy by the Russian Academic Excellence Project '5-100'. The text on 'Synergistics' and the synergistic toolkit is based on material posted on the website www.urban3.net, for which access we are grateful. 
Table 1: Synergy foresight: dimensions and components

\begin{tabular}{|c|c|c|c|}
\hline $\begin{array}{c}\text { CO-EVOLUTIONARY } \\
\text { LEVELS }\end{array}$ & $\begin{array}{c}1.0 \\
\text { Linear: }\end{array}$ & $\begin{array}{c}\mathbf{2 . 0} \\
\text { Evolutionary }\end{array}$ & $\begin{array}{c}3.0 \\
\text { Co-evolutionary }\end{array}$ \\
\hline SYSTEM FRAME & Complexity & Emergent complexity & $\begin{array}{c}\text { Cognitive-collaborative } \\
\text { complexity }\end{array}$ \\
\hline $\begin{array}{c}\text { Foresight purpose } \& \\
\text { context }\end{array}$ & $\begin{array}{c}\text { Identify problems \& } \\
\text { solutions }\end{array}$ & $\begin{array}{l}\text { Explore opportunities } \\
\text { for growth \& } \\
\text { enterprise }\end{array}$ & $\begin{array}{c}\text { Explore potential for } \\
\text { learning \& system } \\
\text { transformation }\end{array}$ \\
\hline Foresight output & Action plan & Road-mapping & Pathway mapping \\
\hline \multicolumn{4}{|l|}{$\begin{array}{l}\text { FORESIGHT } \\
\text { DIMENSIONS }\end{array}$} \\
\hline $\begin{array}{c}\text { 'Subject' of foresight: } \\
\text { sponsors \& users }\end{array}$ & $\begin{array}{l}\text { 'Clever', hierarchical, } \\
\text { static, single value }\end{array}$ & $\begin{array}{c}\text { 'Smart', competitive, } \\
\text { innovative enterprise, } \\
\text { several values }\end{array}$ & $\begin{array}{c}\text { 'Wise', learning, } \\
\text { thinking communities, } \\
\text { multiple values }\end{array}$ \\
\hline $\begin{array}{l}\text { 'Process' of foresight: } \\
\text { methods \& tools }\end{array}$ & $\begin{array}{l}\text { Rational management } \\
\text { / 'logical framework' }\end{array}$ & $\begin{array}{c}\text { Creative \& } \\
\text { entrepreneurial design } \\
\text { process }\end{array}$ & $\begin{array}{c}\text { Deliberative \& social } \\
\text { learning process }\end{array}$ \\
\hline $\begin{array}{l}\text { 'Agenda' of foresight: } \\
\text { the higher intention of } \\
\text { the programme }\end{array}$ & $\begin{array}{l}\text { Normative goals based } \\
\text { on linear projection of } \\
\text { material needs / wants }\end{array}$ & $\begin{array}{c}\text { Normative goals based } \\
\text { on aspirations \& } \\
\text { adaptive futures }\end{array}$ & $\begin{array}{l}\text { Normative goals based } \\
\text { on aspirations \& } \\
\text { system transformation }\end{array}$ \\
\hline $\begin{array}{l}\text { 'Object' of foresight: } \\
\text { system \& change to be } \\
\text { investigated }\end{array}$ & $\begin{array}{l}\text { Linear change in } \\
\text { known factors }\end{array}$ & $\begin{array}{l}\text { Emergent change in } \\
\text { known factors: } \\
\text { markets, enterprises }\end{array}$ & $\begin{array}{l}\text { Cognitive system } \\
\text { transformation with } \\
\text { many unknowns }\end{array}$ \\
\hline
\end{tabular}


Table 2: Application to strategic urban co-intelligence

\begin{tabular}{|c|c|c|c|}
\hline $\begin{array}{c}\text { CO-EVOLUTIONARY } \\
\text { LEVELS }\end{array}$ & $\begin{array}{c}1.0 \\
\text { Linear }\end{array}$ & $\begin{array}{c}2.0 \\
\text { Evolutionary }\end{array}$ & $\begin{array}{c}3.0 \\
\text { Co-evolutionary }\end{array}$ \\
\hline \multicolumn{4}{|l|}{$\begin{array}{l}\text { URBAN POLICY } \\
\text { SECTORS }\end{array}$} \\
\hline Demographics & $\begin{array}{l}\text { Population forecasts } \\
\text { (minor uncertainties) }\end{array}$ & $\begin{array}{c}\text { Projections (major } \\
\text { uncertainties) }\end{array}$ & $\begin{array}{c}\text { Restructuring (major } \\
\text { transformations) }\end{array}$ \\
\hline Spatial planning & $\begin{array}{l}\text { Location for specific } \\
\text { requirements }\end{array}$ & $\begin{array}{c}\text { Space for enterprise } \& \\
\text { opportunity }\end{array}$ & $\begin{array}{l}\text { Liveable communities } \\
\text { \& viable economies }\end{array}$ \\
\hline Housing, community & Housing numbers & Housing markets & $\begin{array}{l}\text { Liveable housing \& } \\
\text { inclusive communities }\end{array}$ \\
\hline $\begin{array}{c}\text { Urban infrastructure \& } \\
\text { public services }\end{array}$ & $\begin{array}{l}\text { Supply to meet } \\
\text { demand forecasts }\end{array}$ & $\begin{array}{c}\text { Markets for } \\
\text { investment \& supply }\end{array}$ & $\begin{array}{c}\text { Rethinking services as } \\
\text { co-production etc. }\end{array}$ \\
\hline $\begin{array}{l}\text { Environment, } \\
\text { ecosystems etc }\end{array}$ & Simple env. targets & $\begin{array}{l}\text { Env. negotiation, } \\
\text { markets, offsets etc }\end{array}$ & $\begin{array}{c}\text { Integrated low carbon } \\
\text { transition etc. }\end{array}$ \\
\hline
\end{tabular}


Figure 1

\section{Synergy foresight: 'subject-process' mapping}

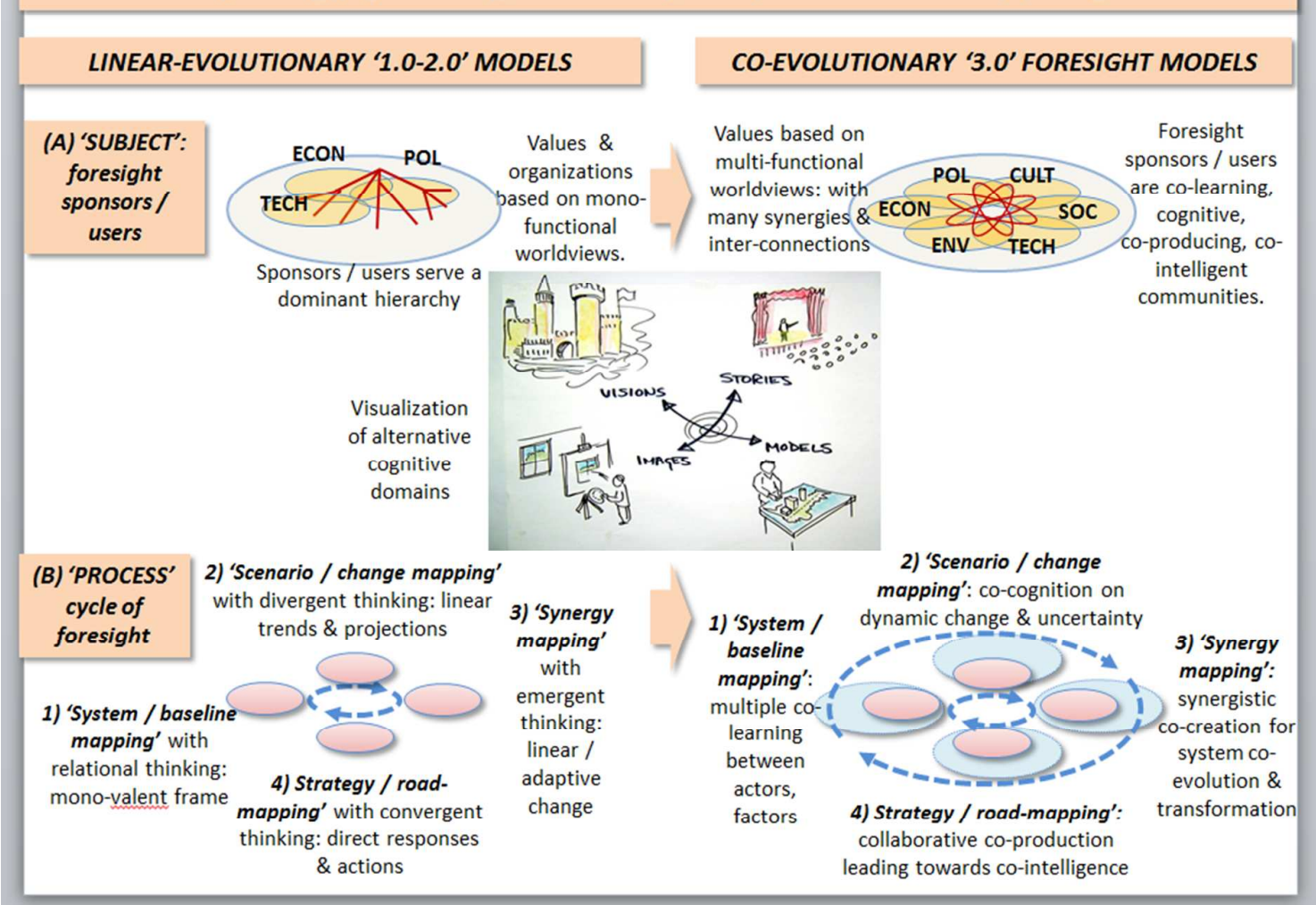




\section{LINEAR-EVOLUTIONARY'1.0-2.0' MODELS}

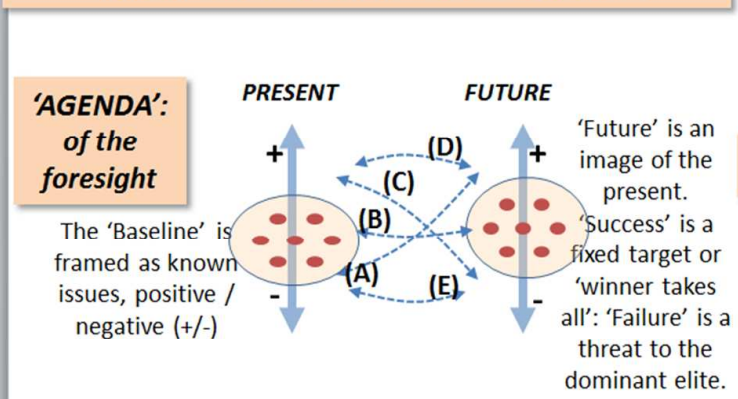

'OBJECT':

of enquiry: issue under investigation

Linear, hierarchical, winner-takes-all competitive system

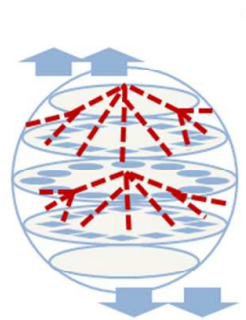

(Visualization as a crystal ball / spherical set of round tables)

Positive values are extracted: negative impacts are externalized
CO-EVOLUTIONARY '3.0' FORESIGHT MODELS
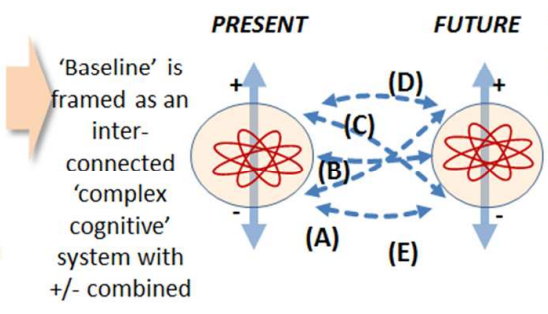

'The future' is a transformation from the seeds of the present. 'Success' is a vision for coevolution.

'Failure' is a deferred success...

\section{Figure 2

Synergistic, collaborative co-learning \& co-intelligent system features

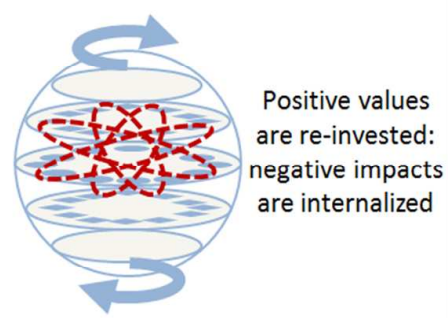




\section{'Synergy Foresight': visual thinking}

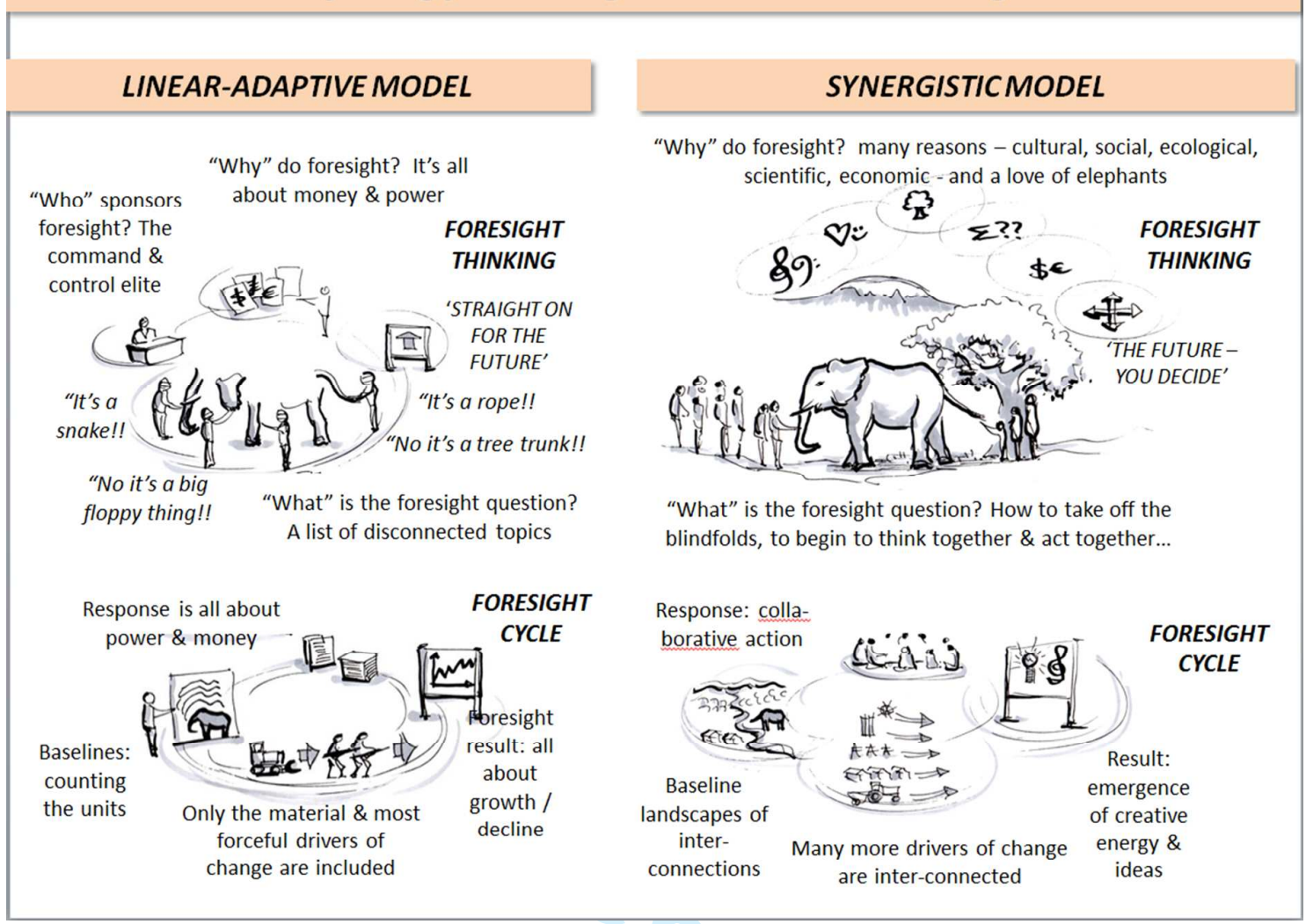

Figure 3 


\section{City Foresight Platform : 'Mini-Lab' prototype}

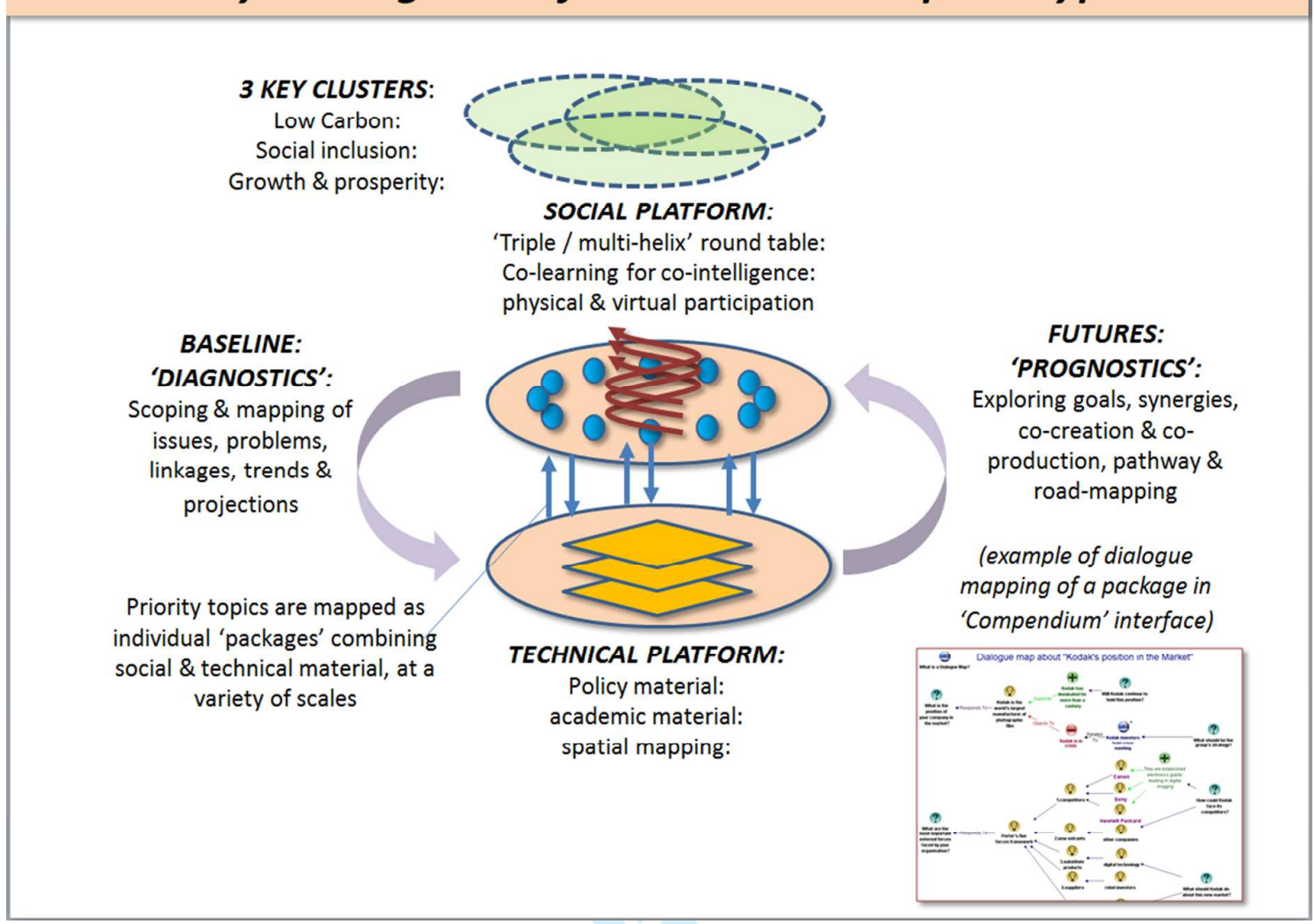

Figure 4 